\title{
Physiological quality of seeds of crambe desiccated at pre-harvest with glyphosate
}

\author{
Lucas V. de S. Cangussú ${ }^{1}$, Andréia M. S. de S. David ${ }^{1}$, Eduardo F. Araújo², \\ Rayane A. Alves ${ }^{1}$, Rebeca A. Nunes ${ }^{1} \&$ Hugo T. R. Amaro ${ }^{3}$
}

${ }^{1}$ Universidade Estadual de Montes Claros/Centro de Ciências Exatas e Tecnológicas/Departamento de Ciências Agrárias. Janaúba, MG. E-mail: lucasvscagro@hotmail.com (Corresponding author) - ORCID: 0000-0002-3454-5864; andreia.david@unimontes.br - ORCID: 0000-0002-2747-5941; rayaneaguiaralves@gmail.com - ORCID: 0000-0002-1614-3239; rebeca.nunnes@hotmail.com - ORCID: 0000-0002-2174-3503

${ }^{2}$ Universidade Federal de Viçosa/Centro de Ciências Agrárias/Departamento de Fitotecnia. Viçosa, MG. E-mail: efaraujo@ufv.br - ORCID: 0000-00031501-0191

${ }^{3}$ Universidade Estadual de Montes Claros/Centro de Ciências Exatas e Tecnológicas/Departamento de Ciências Agrárias. Paracatu, MG. E-mail: hugo.amaro@unimontes.br - ORCID: 0000-0002-3997-9581

\section{Key words:}

Crambe abyssinica

Brassicaceae

maturation

herbicide

germination

\begin{abstract}
A B S T R A C T
Early harvest may decrease seed exposure in the field after physiological maturation. The objective of this study was to evaluate the effect of glyphosate desiccant at different plant desiccation times at pre-harvest on the physiological quality of crambe (Crambe abyssinica Hochst) seeds. The experimental design was completely randomized in a $2 \mathrm{x} 4$ factorial scheme, involving the application of glyphosate desiccant in the plants at pre-harvest and the control (without plant desiccation) and four desiccation times, with three replicates per treatment. The desiccation of crambe plants at pre-harvest with glyphosate was efficient, positively affecting seed germination and vigor. Application of the desiccant in the plants, with $90 \%$ of brown seeds, at 103 days after sowing, allows the production of seeds with superior performance.
\end{abstract}

\section{Palavras-chave: \\ Crambe abyssinica \\ Brassicaceae \\ maturação \\ herbicida \\ germinação}

\section{Qualidade fisiológica de sementes de crambe dessecado em pré-colheita com glyphosate}

\section{R E S U M O}

A antecipação da colheita pode diminuir a exposição das sementes no campo após a maturação fisiológica. Objetivou-se avaliar o efeito do dessecante glyphosate em diferentes épocas de dessecação das plantas em pré-colheita na qualidade fisiológica de sementes de crambe (Crambe abyssinica Hochst). Foi utilizado o delineamento experimental inteiramente casualizado em esquema fatorial 2 x 4, envolvendo a aplicação de dessecante glyphosate nas plantas em pré-colheita e a testemunha (sem dessecação das plantas), e quatro épocas de dessecação, com três repetições por tratamento. A dessecação das plantas de crambe em pré-colheita com glyphosate se mostrou eficiente, afetando positivamente a germinação e o vigor das sementes. A aplicação do dessecante nas plantas, com $90 \%$ das sementes de coloração marrom, aos 103 dias após a semeadura, possibilita a produção de sementes com desempenho superior. 


\section{INTRODUCTION}

Crambe (Crambe abyssinica Hochst) is an oilseed species that can have up to $38 \%$ of oil content in its seeds (Pitol et al., 2010). In oilseed crops, the oil obtained from extraction of the seeds has stood out in the biofuel production for being a renewable source, reducing the use of fossil fuels.

Crambe is a species with indeterminate flowering habit, and the same plant have seeds at different maturity stages (Oliveira et al., 2014); its flowering and, consequently, seed production occur for a long period, which evidences the effects of maturation on seed quality. Harvesting at the right moment is fundamental to preserve seed quality because early harvest may lead to increased deterioration due to high moisture content, whereas late harvests leave the seeds exposed to the unfavorable conditions of the environment, compromising their quality.

Seed physiological quality is an essential factor for the performance of the crop in the field and is characterized by longevity, germination and vigor (Kappes et al., 2012). Thus, the effects on seeds consist in reduction of germination percentage, increase in the number of abnormal seedlings and reduction in seedling vigor (Toledo et al., 2009).

One alternative that can be employed to reduce seed deterioration in the field is the application of desiccating herbicides, which are applied to allow early harvest and uniformize seed maturation, ensuring better quality. Glyphosate is among the most used desiccating herbicides, a product that is post-emergence and with systemic action, belonging to the substituted glycine chemical group (Vargas et al., 2007).

Thus, this study aimed to evaluate the effect of glyphosate desiccant at different plant desiccation times at pre-harvest on the physiological quality of crambe seeds.

\section{Material ANd Methods}

The study was carried out from December 2016 to May 2017, at the State University of Montes Claros - Unimontes, in the Department of Agrarian Sciences, Janaúba, MG, Brazil (15 $48^{\prime} 32^{\prime \prime} \mathrm{S} ; 43^{\circ} 19^{\prime} 31^{\prime \prime} \mathrm{W} ; 533 \mathrm{~m}$ ), in two experimental steps. The first step was conducted in a greenhouse with constant temperature $25 \pm 3{ }^{\circ} \mathrm{C}$ and relative humidity of $60 \pm 3 \%$, recorded along the experiment. The second step was conducted at the Laboratory of Seed Analysis of the Unimontes.

The experiment used seeds of crambe, cultivar 'FMS Brilhante', 2014 season, from the Cooperativa Agropecuária Pioneira (COOAPI), Chapada Gaúcha, MG, at geographic coordinates: $15^{\circ} 28^{\prime} 6^{\prime \prime} \mathrm{S}, 45^{\circ} 25^{\prime} 6^{\prime \prime} \mathrm{W}$, at altitude of $624 \mathrm{~m}$.

The experimental design was completely randomized in 2 $\mathrm{x} 4$ factorial scheme, involving the application of glyphosate in the plants at pre-harvest and the control (without plant desiccation), and four desiccation times based on the stages of seed maturation, detected through visual observation of the percentage of brown seeds (45, 60, 75 and 90\%), which occurred at 88, 93, 98 and 103 days after sowing (DAS). Three experimental units (replicates) were used, each one represented by one pot containing one crambe plant.
Before sowing, the seeds were treated with the fungicide Carbendazim, at dose of $200 \mathrm{~mL}$ of the commercial product per $100 \mathrm{~kg}$ of seeds, and then planted at $2 \mathrm{~cm}$ depth in $7-\mathrm{L}$ plastic pots, in number of five seeds per pot. After germination and emergence, when seedlings showed the second true leaf, thinning was performed to leave only one seedling per pot.

The substrate used was composed of sand, slope soil and manure at 1:1:1 proportion, based on volume. The characterization of soil chemical and physical attributes, in the 0-20 cm layer, showed the following results: $\mathrm{pH}$ in water: 6.80; OM (\%): 1.00; P (Mehlich): $78.10 \mathrm{mg} \mathrm{dm}^{-3} ; \mathrm{K}: 131 \mathrm{mg} \mathrm{dm}^{-3}$; Ca: $2.4 \mathrm{cmol}_{\mathrm{c}} \mathrm{dm}^{-3} ; \mathrm{Mg}^{0} 0.9 \mathrm{cmol}_{\mathrm{c}}$; Exchangeable Al: $0.00 \mathrm{cmol}_{\mathrm{c}} \mathrm{dm}^{-3}$; V: 79\% (Ribeiro et al., 1999).

Fertilization was performed as recommended by Cantarutti et al. (1999) and consisted in the application of $1.55 \mathrm{~g}$ of urea, $31.18 \mathrm{~g}$ of triple superphosphate and $2.17 \mathrm{~g}$ of potassium chloride per pot at planting; and $15.59 \mathrm{~g}$ of urea as top-dressing fertilization at 15 days after planting. Irrigation was manually applied twice a day, in the early morning and late afternoon, according to the crop need.

Desiccation was performed using the herbicide glyphosate (2.0 L ha-1 of a.i.) applied using a backpack sprayer with capacity for $20 \mathrm{~L}$ of mixture. In plants that did not receive desiccant application, harvests were performed at 88, 93, 98 and 103 DAS, which respectively corresponded to the periods 1, 2, 3 and 4 . For plants that received glyphosate application, a 7-day interval was used between herbicide application and seed harvest.

All racemes of the plants from the respective treatments were manually harvested, placed in plastic bags and sent to the laboratory. Seeds were manually extracted and immediately subjected to moisture content determination by the oven method at $105 \pm 3{ }^{\circ} \mathrm{C}$ for $24 \mathrm{~h}$ (Brasil, 2009). Then, the remaining seeds were immersed for $2 \mathrm{~min}$ in a $2 \%$ sodium hypochlorite solution and washed in running water for 5 min. After that, they were dried on paper towel under room conditions at the laboratory for $24 \mathrm{~h}$ until reaching moisture content of approximately $10 \%$.

For the germination test, the seeds were distributed on two sheets of Germitest paper, moistened with a volume of distilled water equivalent to 2.5 times their dry weight, in plastic boxes $\left(G^{-}\right.$rbox $\left.^{\circledast}\right)$. The boxes were maintained in germinator at temperature of $25^{\circ} \mathrm{C}$. Evaluations were carried out on the fourth (first count of germination) and seventh days after sowing, and the results were expressed in percentage of normal seedlings, according to the criteria established by the Rules for Seed Analysis - RAS (Brasil, 2009).

Emergence speed index (ESI) was determined under laboratory conditions $\left(25^{\circ} \mathrm{C}\right)$, using washed and sterilized sand as substrate. The seeds were planted at $2 \mathrm{~cm}$ depth in plastic boxes $\left(\right.$ Gerbox $\left.^{\circledR}\right)$ containing the substrate moistened with water volume equivalent to $50 \%$ the retention capacity (Brasil, 2009), and moisture levels were maintained by daily irrigation. ESI was determined by daily counting the number of emerged seedlings until 7 DAS (Maguire, 1962).

The method proposed by Marcos Filho (1999) was used to determine the accelerated aging, by placing approximately 250 seeds uniformly distributed on aluminum screen, attached to the interior of the Gerbox plastic box, containing $40 \mathrm{~mL}$ of 
distilled water at the bottom. The boxes were closed and kept in Biochemical Oxygen Demand (B.O.D.) incubation chamber at $43^{\circ} \mathrm{C}$ for $72 \mathrm{~h}$. After this period, three replicates of 50 seeds were subjected to germination test, as previously described, and the results were expressed in percentage of normal seedlings obtained at 4 DAS.

Electrical conductivity was evaluated using three replicates of 50 seeds, weighed and placed in $200-\mathrm{mL}$ plastic cups containing $75 \mathrm{~mL}$ of distilled water. The cups were taken to the B.O.D. chamber at $25^{\circ} \mathrm{C}$ for $24 \mathrm{~h}$. Readings were taken using a DM-31 conductivity meter and the results were expressed in $\mu \mathrm{S} \mathrm{cm}^{-1} \mathrm{~g}^{-1}$ of seeds (Vieira et al., 2002).

The results were subjected to analysis of variance and when significant, the effects of desiccant application and control (without plant desiccation) were analysed by $\mathrm{F}$ test at 0.05 significance level, whereas the effects of desiccant application times were studied by regression analysis, selecting the most adequate models to represent them based on biological behavior, significance of model coefficients and coefficient of determination $\left(\mathrm{R}^{2}\right)$.

\section{Results AND Discussion}

The joint analysis of variance of the characteristics evaluated revealed significant effect only for the isolated factors on emergence speed index. For the other variables, there were significant interactions between desiccant application and time of application.

Plant desiccation with the herbicide glyphosate at the times 1, 2 and 3 was efficient at reducing seed moisture content (Table 1). Besides promoting the drying, desiccation causes benefits such as uniform maturation and easy harvest, which reduces the costs with drying and cleaning of seeds (Inoue et al., 2003).

Table 1. Moisture content (MC), germination (GER), first count of germination (FCG), emergence speed index (ESI), accelerated aging (AA) and electrical conductivity (EC) of crambe seeds, with and without plant desiccation at pre-harvest with glyphosate, at different application times

\begin{tabular}{|c|c|c|c|c|c|}
\hline \multirow{2}{*}{ Desiccant } & \multicolumn{4}{|c|}{ Application Times } & \multirow{2}{*}{$\begin{array}{l}\text { CV } \\
\text { (\%) }\end{array}$} \\
\hline & 1 & 2 & 3 & 4 & \\
\hline & \multicolumn{5}{|c|}{ MC (\%) } \\
\hline With & $11.9 \mathrm{~B}$ & $9.7 \mathrm{~B}$ & $6.6 \mathrm{~B}$ & $8.6 \mathrm{~A}$ & \multirow{2}{*}{23.33} \\
\hline Without & $44.1 \mathrm{~A}$ & $20.6 \mathrm{~A}$ & $12.8 \mathrm{~A}$ & $7.0 \mathrm{~A}$ & \\
\hline & \multicolumn{5}{|c|}{ GER (\%) } \\
\hline With & $30 \mathrm{~A}$ & $33 \mathrm{~A}$ & $41 \mathrm{~A}$ & $78 \mathrm{~A}$ & \multirow{2}{*}{34.75} \\
\hline Without & $7 \mathrm{~B}$ & $21 \mathrm{~A}$ & $33 \mathrm{~A}$ & $20 \mathrm{~B}$ & \\
\hline & \multicolumn{5}{|c|}{ FCG (\%) } \\
\hline With & $19 \mathrm{~A}$ & $31 \mathrm{~A}$ & $37 \mathrm{~A}$ & $77 \mathrm{~A}$ & \multirow{2}{*}{41.87} \\
\hline Without & $2 \mathrm{~A}$ & $12 \mathrm{~A}$ & $27 \mathrm{~A}$ & $9 \mathrm{~B}$ & \\
\hline & \multicolumn{5}{|c|}{ ESI } \\
\hline With & $4.5 \mathrm{~A}$ & $5.4 \mathrm{~A}$ & $8.6 \mathrm{~A}$ & $12.6 \mathrm{~A}$ & \multirow{2}{*}{32.54} \\
\hline Without & $1.1 \mathrm{~A}$ & $2.8 \mathrm{~A}$ & $5.6 \mathrm{~A}$ & $5.0 \mathrm{~B}$ & \\
\hline & \multicolumn{5}{|c|}{$\mathrm{AA}(\%)$} \\
\hline With & $59 \mathrm{~A}$ & $57 \mathrm{~B}$ & $53 \mathrm{~B}$ & $66 \mathrm{~B}$ & \multirow{2}{*}{20.40} \\
\hline Without & $38 \mathrm{~B}$ & $76 \mathrm{~A}$ & $71 \mathrm{~A}$ & $77 \mathrm{~A}$ & \\
\hline & \multicolumn{5}{|c|}{ 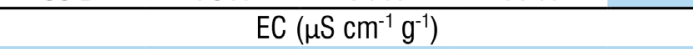 } \\
\hline With & $574.427 \mathrm{~A}$ & $463.890 \mathrm{~A}$ & $399.087 \mathrm{~A}$ & $535.760 \mathrm{~A}$ & \multirow{2}{*}{12.04} \\
\hline Without & $450.037 \mathrm{~B}$ & $427.053 \mathrm{~A}$ & $483.910 \mathrm{~A}$ & $448.673 \mathrm{~A}$ & \\
\hline
\end{tabular}

Means followed by the same letter in the column do not differ by $F$ test at 0.05 significance level; 1 - 88 days after sowing (DAS) - 45\% of brown seeds; 2 - 93 DAS - 60\% of brown seeds; 3 - 98 DAS - 75\% of brown seeds; 4 - 103 DAS - $90 \%$ of brown seeds
At time 1, seeds harvested from desiccated plants already had moisture contents (11.9\%) compatible with the mechanical harvest (Table 1). At the fourth application time (103 DAS), the produced seeds showed moisture contents similar to those of seeds from non-desiccated plants.

Germination (Table 1) was positively affected by plant desiccation at the first application time (88 DAS), and the values were statistically superior to those of the control (without desiccation). At the times 2 and 3, there was no difference in germination between treatments with the desiccant and the control. However, plant desiccation at the time 4 positively affected seed germination in comparison to the control, with mean values of $78 \%$ (Table 1). It is worth highlighting that this percentage is higher than the minimum percentage required for production and commercialization of basic crambe seeds, which is $60 \%$, according to the ordinance $n^{\circ} 16$, of January 25 , 2013 (Brasil, 2013).

Desiccants have been used to uniformize maturation and promote early harvest of seeds in various crops, such as soybean (Daltro et al., 2010; Marcandalli et al., 2011; Toledo et al., 2014), canola (Silva et al., 2011) and common beans (Kappes et al., 2012; Franco et al., 2013). However, Daltro et al. (2010) observed that glyphosate negatively interfered with germination and initial development of soybean seedlings, particularly hampering their roots due to the phytotoxic effect caused by the desiccant.

As observed for germination, seed vigor evaluated by the first count test was positively influenced by plant desiccation at the fourth application time (Table 1). The first count of germination is a simple test of vigor, performed simultaneously to the germination test, and is based on the assumption that more vigorous seeds germinate faster. Obtaining vigorous seeds is fundamental because vigor level can affect crop establishment, plant development and plantation uniformity (Daltro et al., 2010).

The results of emergence speed index (Table 1) demonstrated favorable effect of the desiccant at the fourth time of application (103 DAS), showing values higher than those of the control. Higher ESI values indicate that seeds originated from plants desiccated at the fourth time emerged faster and more uniformly, thus being more vigorous. For the other times, there was no difference between desiccant application and the control.

This practice promotes advantages such as reduction of moisture, uniform maturation and preservation of seed physiological quality, due to the lower exposure to inclement weather and fluctuations of humidity, minimizing the irreversible damages of the deterioration by moisture (Lacerda et al., 2003, Kappes et al., 2009).

The desiccation of crambe plants favored seed germination after accelerated aging at the first time of application (Table 1). For the other times, seeds originated from non-desiccated plants showed higher germination than seeds from desiccated plants. Unlike the other tests, seeds from non-desiccated plants, even after subjected to aging stress conditions, reached germination above the minimum required for seed commercialization, as previously described. These results suggest that the conditions promoted by the test may have contributed to overcoming seed 
dormancy. Thus, West (1992) highlights that the accelerated aging test has caused overcoming of seed dormancy in some forage grasses.

Vigor tests, such as the accelerated aging, are employed to evaluate the physiological quality of seeds when they are subjected to specific conditions of stress.

Regarding the electrical conductivity (Table 1), seeds from non-desiccated plants (control) at time 1 showed lower values in comparison to seeds from desiccated plants. Lower values of electrical conductivity correspond to the lower release of exudates and indicate higher physiological potential (vigor) and lower intensity of disorganization of cell membranes in the seeds (Castro et al., 2016). There was no difference between the treatments for the other times.

The behavior of seed moisture content as a function of the times of plant desiccation with glyphosate is presented in Figure 1A. The mean moisture content in the seeds after plant desiccation was equal to $9.21 \%$. Seeds with moisture content higher than the ideal for harvest were incompatible with the mechanical harvest, because they are more subject to severe levels of mechanical damage by deformation.

For seeds produced in the absence of desiccation, the results of moisture fitted to a decreasing linear regression equation, and the reduction in moisture content was proportional to harvest time, with value of $3.27 \%$ in the seeds from the last harvest (Figure 1A). After physiological maturity, there is a natural process of drying, which continues until the seeds reach a point of equilibrium with the relative air humidity (Marcos Filho, 2015).

Seed germination (Figure 1B) increased along the times of desiccant application. Initially (time 1), the seeds showed $23 \%$ germination, which increased to $68 \%$ at the fourth time

A. With desiccation $=\bar{y}=\dot{x}=9.21$

Without desication $=\bar{y}=248.731733^{*}-2.383133^{*} \times R^{2}: 0.89$
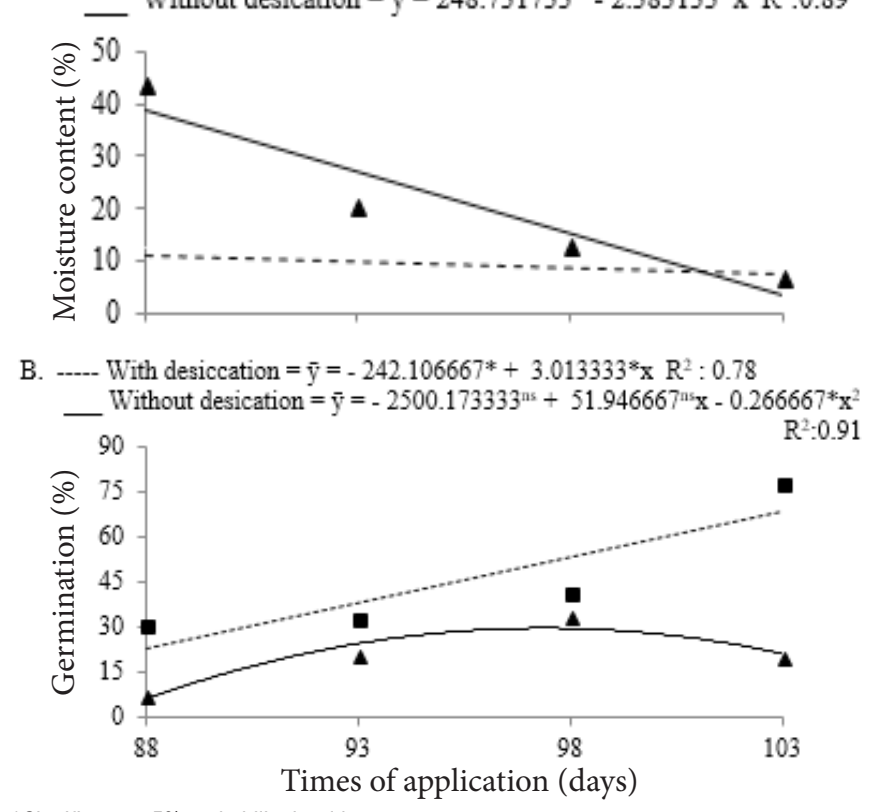

*Significant at $5 \%$ probability level by t-test

Ns Not significant at $5 \%$ probability level by t-test

Figure 1. Moisture content (A) and germination (B) of crambe (Crambe abyssinica Hoechst) seeds with and without plant desiccation at pre-harvest with glyphosate, at different times of application of application, meeting the minimum standard for production and commercialization of crambe seeds, as previously reported.

In the absence of desiccation (Figure 1B), there was an increase in the germination percentage of seeds from the first harvest time (98 DAS), when maximum germination occurred (31\%), followed by a reduction $(21 \%)$ in the last time (103 DAS). The low germination percentages observed in seeds from non-desiccated plants can be associated with the non-uniform maturation of the crambe crop, which leads to different degrees of dormancy in the seeds along the harvests (Costa et al., 2011). The results of vigor (Figure 2A) in the seeds from desiccated plants, evaluated by the first count test, fitted to an increasing linear regression equation.

Initially (time 1), the seeds led to a percentage of normal seedlings of approximately $14 \%$ at the first count, reaching the maximum value $(68 \%)$ at the fourth time of application (Figure $2 \mathrm{~A})$. The desiccation practice to minimize problems of delay in harvest has been reported in various crops, with advantages such as the possibility of planning the harvest and reduction in the damages caused by pests and fungi, which may attack the crop at the end of the cycle (Daltro et al., 2010).

For seeds originated from non-desiccated plants, there was a quadratic behavior along the harvest times (Figure 2A), and the maximum percentage of normal seedlings at the first count $(21 \%)$ was recorded at 97 days. From this time on, the values decreased, which can be associated with the post-harvest dormancy of crambe seeds, as previously reported.

For the ESI (Figure 2B), there was no effect of treatments with and without desiccation of crambe plants, at the different times, and the highest mean of ESI (8.90) was observed at time 4.

The germination of seeds from desiccated plants after the accelerated aging (Figure 3A) was not influenced by the

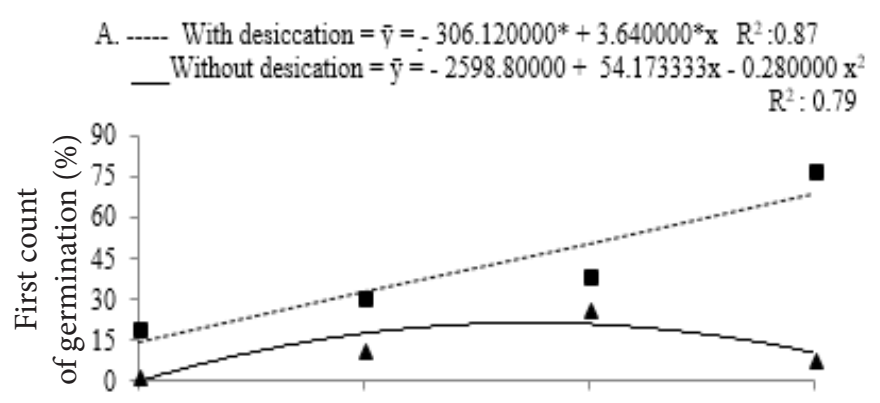

B. $\quad \bar{y}=-34.709400+0.423467 * x R^{2}: 0.98$

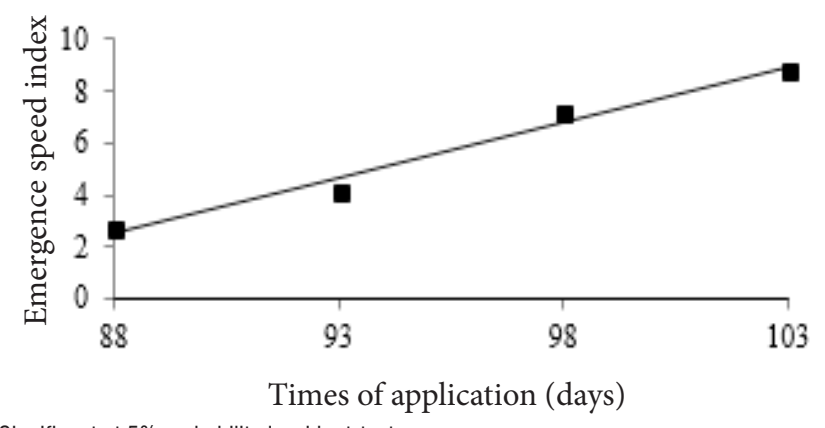

* Significant at $5 \%$ probability level by t-test

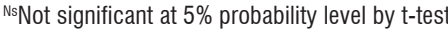

Figure 2. First count of germination (A) and emergence speed index - ESI (B) of crambe (Crambe abyssinica Hoechst), with and without plant desiccation at pre-harvest with glyphosate, at different times of application 
different times of glyphosate application, maintaining a mean value of $58 \%$. Toledo et al. (2014) observed that the germination of soybean seeds, after accelerated aging, was reduced with the desiccation of the plants at pre-harvest, due to the increase in the percentage of abnormal seedlings.

Defining the desiccant application time is indispensable for the efficiency of the product, because applications performed far away from the period of seed physiological maturity or under unfavorable conditions of climate, especially rainy periods, can compromise seed quality (Santos et al., 2005).

For seeds produced by non-desiccated plants, the results of germination after accelerated aging fitted to a quadratic model, and maximum germination $(79.23 \%)$ occurred in seeds from the third harvest time. However, from this point on, there was a reduction in the values, finishing with a germination of $74.03 \%$ at the fourth harvest time.

In the evaluation of electrical conductivity (Figure 3B), it is possible to note that at the time 1 the seeds from desiccated plants showed higher values than non-desiccated seeds. In seeds without desiccation, there was no difference between times, maintaining a mean value of $452.42 \mu \mathrm{S} \mathrm{cm}^{-1} \mathrm{~g}^{-1}$.

It is important to point out that, although plant desiccation at all times of application was efficient for seeds to reach ideal moisture for harvest, in general, seeds with better physiological quality were obtained only at the last time (103 DAS), in comparison to the non-desiccated ones. At 103 DAS, desiccation with the herbicide glyphosate led to a $290 \%$ increase in germination percentage in comparison to the control (Figure 1B). These results suggest a possible overcoming of the dormancy of seeds from desiccated plants, but it becomes evident the need for further research because there are no studies related to the application of desiccants in the crambe crop.

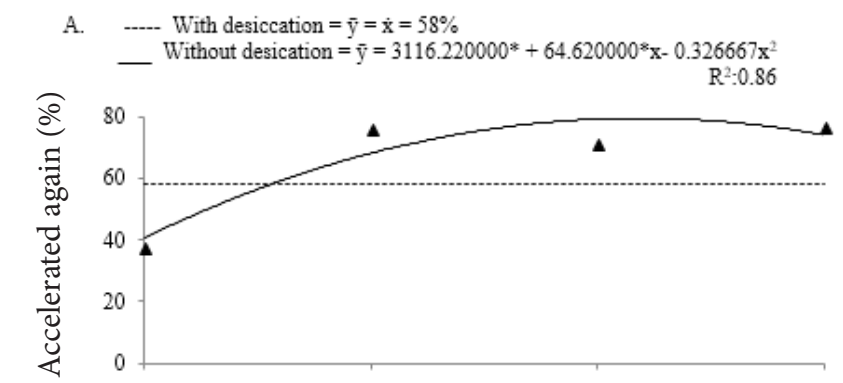

B. With desiccation $=\bar{y}=23307.542100 *-475.787167 * x+2.472100 x^{2}$

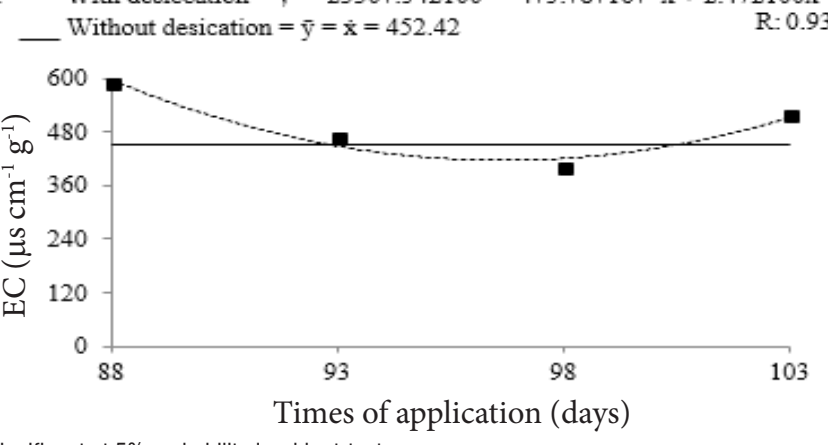

* Significant at $5 \%$ probability level by t-test

Ns Not significant at $5 \%$ probability level by t-test

Figure 3. Accelerated aging (A) and electrical conductivity - EC (B) of crambe (Crambe abyssinica Hoechst) seeds, with and without plant desiccation at pre-harvest with glyphosate, at different times of application

\section{Conclusions}

1. Desiccation of crambe plants at pre-harvest with glyphosate proved to be efficient, positively affecting seed germination and vigor.

2. Desiccant application in the plants, with $90 \%$ of brown seeds, at 103 days after sowing, allows the production of seeds with superior performance.

\section{ACknowledgments}

To the National Council for Scientific and Technological Development (CNPq), to the Coordination for the Improvement of Higher Education Personnel (CAPES) and to the Minas Gerais Research Support Foundation (FAPEMIG) for the scholarships and financial support.

\section{Literature Cited}

Brasil. Ministério da Agricultura, Pecuária e Abastecimento. Secretaria de Defesa Agropecuária. Regras para análise de sementes. Brasília: MAPA, 2009. 395p.

Brasil. Ministério da Agricultura, Pecuária e Abastecimento. Portaria $\mathrm{n}^{\circ}$ 16, de 25 de Janeiro de 2013. Brasília: MAPA, 2013. 17p.

Cantarutti, R. B.; Martins, C. E.; Carvalho, M. M.; Fonseca, D. M.; Arruda, M. L.; Vilela, H.; Oliveira, F. T. T. Pastagens. In: Ribeiro, A. C.; Guimarães, P. T. G.; Alvarez V., V. H. Recomendações para o uso de corretivos e fertilizantes em Minas Gerais. 5.aprox. Viçosa: Comissão de Fertilidade do Solo do Estado de Minas Gerais, 1999. p.332-341.

Castro, E. M.; Oliveira, J. A.; Lima, A. E.; Santos, H. O.; Barbosa, J. I. L. Physiological quality of soybean seeds produced under artificial rain in the pre-harvesting period. Journal of Seed Science, v.38, p.14-21, 2016. https://doi.org/10.1590/2317-1545v38n1154236

Costa, L. M.; Resende, O.; Gonçalves, D. N.; Sousa, K. A. Coeficiente de difusão efetivo para a secagem de sementes de crambe (Crambe abyssinica). Revista Brasileira de Engenharia Agrícola e Ambiental, v.15, p.1089-1096, 2011. https://doi.org/10.1590/ S1415-43662011001000014

Daltro, E. M. F.; Albuquerque, M. C. de. F.; França Neto, J. de B.; Guimarães, S. C.; Gazziero, D. L. P; Henning, A. A. Aplicação de dessecantes em pré-colheita: Efeito na qualidade fisiológica de sementes de soja. Revista Brasileira de Sementes, v.32, p.111-122, 2010. https://doi.org/10.1590/S0101-31222010000100013

Franco, M. H. R.; Nery, M. C.; França, A. C.; Oliveira, M. C.; Franco, G. N.; Lemos, V. T. Produção e qualidade fisiológica de semente de feijão após aplicação do herbicida Diquat. Semina: Ciências Agrárias, v.34, p.1707-1714, 2013. https://doi.org/10.5433/16790359.2013v34n4p1707

Inoue, M. H.; Marchiori, O.; Braccini, A. L.; Oliveira, R. S.; Avilla, M. R. Rendimento de grãos e qualidade de sementes de soja após a aplicação de herbicidas dessecantes. Ciência Rural, v.33, p.769770, 2003. https://doi.org/10.1590/S0103-84782003000400030

Kappes, C.; Arf, O.; Ferreira, J. P.; Portugal, J. R.; Alcalde, A. M.; Arf, M. V.; Vilela, R. G. Qualidade fisiológica de sementes e crescimento de plântulas de feijoeiro, em função de aplicações de paraquat em pré-colheita. Pesquisa Agropecuária Tropical, v.42, p.9-18, 2012. https://doi.org/10.1590/S1983-40632012000100002 
Kappes, C.; Carvalho, M. A. C.; Yamashita, O. M. Potencial fisiológico de sementes de soja dessecadas com diquat e paraquat. Scientia Agraria, v.10, p.1-6, 2009. https://doi.org/10.5380/rsa.v10i1.12520

Lacerda, A. L. S.; Lazarini, E.; Sá, M. E.; Valério Filho, W. V. Armazenamento de sementes de soja dessecadas e avaliação da qualidade fisiológica, bioquímica e sanitária. Revista Brasileira de Sementes, v.25, p.97-105, 2003. https://doi.org/10.1590/S010131222003000400014

Maguire, J. D. Speed of germination and in selection and evaluation for seedlings emergence and vigor. Crop Science, v.2, p.176-177, 1962. https://doi.org/10.2135/cropsci1962.0011183X000200020033x

Marcandalli, L. H.; Lazarini, E.; Malaspina, I. C. Épocas de aplicação de dessecantes na cultura da soja: Qualidade fisiológica de sementes. Revista Brasileira de Sementes, v.33, p.241-250, 2011. https://doi. org/10.1590/S0101-31222011000200006

Marcos Filho, J. Teste de envelhecimento acelerado. In: Krzyzanowski, F. C.; Vieira, R. D.; França Neto, J. B. (eds.). Vigor de sementes: Conceitos e testes. Londrina: ABRATES, 1999. Cap.3, p.1-24.

Marcos Filho, J. Fisiologia de sementes de plantas cultivadas. Londrina: ABRATES, 2015. 659p.

Oliveira, M. B.; David, A. M. S. S.; Amaro, H. T. R.; Assis, M. O.; Rodrigues, B. R. A.; Aspiazu, I.; Carvalho, A. J. Épocas de colheita e qualidade fisiológica de sementes de crambe. Semina: Ciências Agrárias, v.35, p.1785-1792, 2014. https://doi.org/10.5433/16790359.2014v35n4p 1785

Pitol, C.; Broch, D. L.; Roscoe, R. Tecnologia e produção: Crambe 2010. 1.ed. Maracaju: Fundação MS, 2010. 60p.

Ribeiro, A. C.; Guimarães, P. T. G.; Alvarez V., V. H. Recomendações para o uso de corretivos e fertilizantes em Minas Gerais. Viçosa: Comissão de Fertilidade do Solo do Estado de Minas Gerais, 1999. 359p.
Santos, P. M.; Reis, M. S.; Sediyama, T.; Araújo, E. F.; Cecon, P. R.; Santos, M. R. Efeito da classificação por tamanho da semente de soja na sua qualidade fisiológica durante o armazenamento. Acta Scientiarum. Agronomy, v.27, p.395-402, 2005. https://doi. org/10.4025/actasciagron.v27i3.1398

Silva, J. A. G.; Motta, M. B.; Winch, J. A.; Crestani, M.; Fernandes, S. B. V.; Berto, J.; Gaviraghi, F.; Martins, J. A. K.; Wagner, J. F.; Valentini, A. P. F.; Zambonato, F. Dessecação em pré-colheita como estratégia de manejo na redução de perdas por fatores de ambiente em canola. Revista Brasileira de Agrociência, v.17, p.15-24, 2011.

Toledo, M. Z.; Fonseca, N. R.; César, M. L.; Soratto, R. P.; Cavariani, C.; Crusciol, C. A. C. Qualidade fisiológica e armazenamento de sementes de feijão em função da aplicação tardia de nitrogênio em cobertura. Pesquisa Agropecuária Tropical, v.392, p.124-133, 2009.

Toledo, M. Z.; Ishizuka, M. S.; Cavariani, C.; França Neto, J. de B.; Picoli, L. B. Dessecação em pré-colheita com glyphosate e qualidade de sementes armazenadas de soja. Semina: Ciências Agrárias, v.35, p.765-774, 2014. https://doi.org/10.5433/16790359.2014v35n2p765

Vargas, L.; Moraes, R. M. A.; Berto, C. M. Herança da resistência de azevém (Lolium multiflorum) ao glyphosate. Planta Daninha, v.25, p.567-571, 2007. https://doi.org/10.1590/S010083582007000300016

Vieira, R. D.; Penariol, A. L.; Perecin, D.; Panobianco, M. Condutividade elétrica e teor de água inicial das sementes de soja. Pesquisa Agropecuária Brasileira, v.37, p.1333-1338, 2002. https://doi.org/10.1590/S0100-204X2002000900018

West, S. H. Reducing dormancy in Pensacola Bahia grass. Journal of Seed Technology, v.16, p.1-8, 1992. 